\title{
Interest representation in the European Union.
}

\author{
GREENWOOD, J.
}

2017

This is a sample chapter from Greenwood, J., Interest representation of the European Union. Reproduced with permission of Palgrave Macmillan. This extract is taken from the author's original manuscript and has not been edited. The definitive, published, version of record is available here:

https://www.macmillanihe.com/page/detail/Interest-Representation-in-the-European-

$\underline{\text { Union/?K=9781137491312 }}$ 


\section{Citizen Interests}

A striking development is the 'coming of age' of citizen interest organisation, mobilisation, and representation at EU level. There is a dense landscape of NGOs organised and advocating at EU level for virtually every imaginable cause, from the unemployed to Muslim women to groups countering the long-held monopoly of producer groups in technical domains, such as financial services. A number of EU NGOs are also relatively well resourced. One segment alone, environmental NGOs, has over $130 \mathrm{EU}$ orientated staff, and self-declares an annual spend on lobbying the EU institutions of over $€ 13$ million. The WWF European Policy Office, Transport and the Environment, and the European Consumers Organisation, each have a staffing complement comparable to the group of best resourced business organisations, bar one (Table 4.1). EU NGOs have recently located a variety of wealthy independent foundations from which to draw financial support. Individual NGOs are highly networked by formal organisations and informal structures within and across segments, sometimes working alongside one another in purpose renovated buildings, often working on joint campaigns. Manifestos with a coherent outlook for 'people and the planet' (EEB, 2010) are published together by coalition partners with a breadth of scope to match those of political parties standing for election. And, significantly, social movement structures which lie beyond the 'usual suspects' of institutionalised Brussels NGOs have been engaging the EU using various channels, linked to policy making by 'bridge' organisations such as Friends of the Earth and Greenpeace (Hadden, 2015).

As the European Community was driven by the single market agenda in the decade following the corresponding Treaty, so a glance at any of the core contemporary debates since the Treaty on European Union reveal that it has come to be gripped by discourse about its legitimacy. Much of the current debate about this focuses upon input legitimacy (participation and the means through which policies are made) rather than output legitimacy ('winning by results'). This model of 'participatory democracy,' and the systematic empowerment of organised citizen groups as a means to achieve this (Chapters 1 and 8), explains why organisations articulating interests stated as those of the citizen have arrived at the centre of EU policy making. Such organisations have successfully used the discourse of democratic legitimacy for this purpose, 'framing' their demands in these key terms (Börang and Naurin, 2015). The linkage of policy agendas to popular discourse is captured by the concept of 'policy framing', where 'policy actors try to control the 
prevailing image of the policy problem through the use of rhetoric, symbols and policy analysis' (Baumgartner and Jones, in Mazey, 2000, p.339). The all-important ways in which issues are defined and 'framed' create policy priorities and their treatment in the policy process. These factors have helped to propel citizen issues to the fore of EU policy agendas.

A Communication from the European Commission in 2000, 'The Commission and NGOs: Building a Stronger Partnership,' issued in the names of its President and Vice-President, lists six main reasons for co-operation with organised civil society:

- fostering participatory democracy

- as information relays

- representing the views of specific groups of citizens to the EU institutions

- contributing to policy making

- contributing to project management and policy/programme implementation

- contributing to European integration (European Commission, 2000).

These roles are a mixture of 'input' and 'output' legitimacy, and therefore help to explain the activism of EU political institutions in the formation and maintenance of interest groups. As well as responding to incentives provided by EU political institutions (Chapter 1), groups have also emerged to fill 'niches' which are identified and exploited by entrepreneurs. To the above list can also be added the accountability functions exercised by NGOs, by keeping office holders to account. The flip side is that their own accountability is limited in not themselves being accountable to those upon whom their advocacy impacts (Chapter 1).

\section{The Landscape of Citizen I nterest Groups}

NGOs account for around one-quarter of entries on the Transparency Register. The organisational landscape of EU NGOs bears evidence of its institutionalisation, and in particular the emergence of 'family' NGOs. The most highly confederated citizen interest group is the EU Civil Society Contact Group, with a rotating secretariat. It is a 'family of 8 families' of EU citizen interest groups, comprising the: 
TABLE 6.1 Members of the EU Civil Society Contact Group

\begin{tabular}{|c|c|}
\hline Social Platform & $\begin{array}{l}35 \text { (full members) Citizen Interest Groups organised at EU } \\
\text { level in the wider social policy field, spanning demographic } \\
\text { interests and advocacy. Initiated by EU institutions, now a } \\
\text { leading organisation in sector with elevated status in } \\
\text { institutions. } 7 \text { staff. }\end{array}$ \\
\hline CONCORD & $\begin{array}{l}\text { European NGO Confederation for Relief and Development, } \\
\text { comprising } 20 \text { international networks and } 28 \text { national } \\
\text { associations across Europe. Lead partner of DG Development. } \\
13 \text { staff. }\end{array}$ \\
\hline $\begin{array}{l}\text { Human Rights and } \\
\text { Democracy Network }\end{array}$ & $\begin{array}{l}\text { Network organisation of } 50 \text { outlets of international peace, and } \\
\text { human rights, organisations, active at EU level. }\end{array}$ \\
\hline Green10 & $\begin{array}{l}\text { 'Family' network of } 10 \text { environmental NGOs active at EU level, } \\
\text { which purposefully co-ordinates resources between } \\
\text { participating organisations. } 130 \text { staff. }\end{array}$ \\
\hline $\begin{array}{l}\text { European } \quad \text { Women's } \\
\text { Lobby (EWL) }\end{array}$ & $\begin{array}{l}\text { Confederation of } 31 \text { national organisations and } 19 \\
\text { transnational organisations. Secretariat of } 10 \text { staff, plus } \\
\text { interns. }\end{array}$ \\
\hline Culture Action Europe & $\begin{array}{l}\text { Family of } 90 \text { transnational and national member organisations } \\
\text { working on EU culture issues. } 7 \text { staff. }\end{array}$ \\
\hline $\begin{array}{l}\text { European Public Health } \\
\text { Alliance (EPHA) }\end{array}$ & $\begin{array}{l}47 \text { transnational organisations and } 41 \text { national organisations } \\
\text { working in public health field. } 10 \text { staff }+ \text { interns. }\end{array}$ \\
\hline $\begin{array}{l}\text { European Civil Society } \\
\text { Platform on Lifelong } \\
\text { Learning (EUCIS-LLL) }\end{array}$ & $\begin{array}{l}\text { Umbrella of } 40 \text { European networks active in education and } \\
\text { training. } 6 \text { staff. }\end{array}$ \\
\hline
\end{tabular}

Sources: organisation web sites 
A variety of organisations fulfil horizontal niches within the citizen domain alongside the CSCG:

TABLE 6.2 Cross-sectoral EU citizen interest associations not in membership of the Contact Group of Civil Society

\begin{tabular}{|c|c|c|c|}
\hline Name (Acronym) & $\begin{array}{l}\text { Year } \\
\text { Estab. }\end{array}$ & $\begin{array}{l}\text { Social } \\
\text { Platform } \\
\text { Member? }\end{array}$ & Role \\
\hline $\begin{array}{l}\text { European Anti- } \\
\text { Poverty Network } \\
\text { (EAPN) }\end{array}$ & 1990 & Yes & $\begin{array}{l}29 \text { national (and regional \& local) and } 18 \\
\text { European members concerned with } \\
\text { disadvantage. Has developed into a } \\
\text { horizontal type umbrella organisation with } \\
\text { a remit of social inclusion. Heavily } \\
\text { institutionalised in DG EMPL (Bauer, 2002), } \\
\text { and has assumed a formal monitoring role } \\
\text { in the European Employment Strategy. } 7 \\
\text { staff. }\end{array}$ \\
\hline $\begin{array}{l}\text { European Council for } \\
\text { Non-Profit } \\
\text { Organisations } \\
\text { (CEDAG) }\end{array}$ & 1989 & No & $\begin{array}{l}\text { French dominated 'third sector' } \\
\text { organisation, with members from } 8 \\
\text { countries which are national and regional } \\
\text { councils for voluntary organisations as } \\
\text { members. One permanent employee, } \\
\text { supplemented by member resources. Led } \\
\text { the unsuccessful pursuit of a European } \\
\text { Association Statute with DG XXIII of the } \\
\text { European Commission in the 1990s (Kendall } \\
\text { and Fraisse, 2005). }\end{array}$ \\
\hline $\begin{array}{l}\text { European Citizen } \\
\text { Action Service } \\
\text { (ECAS) }\end{array}$ & 1990 & No & $\begin{array}{l}\text { Direct membership organisation, drawn } \\
\text { diversely from over } 100 \mathrm{EU} \text {, national and } \\
\text { regional NGOs with interests in citizen } \\
\text { issues/NGOs. Members diversely drawn } \\
\text { from fields of citizens advice, civil liberties, }\end{array}$ \\
\hline
\end{tabular}




\begin{tabular}{|l|l|l|l|}
\hline & & & $\begin{array}{l}\text { culture, development, health and social } \\
\text { welfare, local government, general civil } \\
\text { society development agencies. Active on } \\
\text { direct democracy, free movement of } \\
\text { citizens, and European governance. } \\
\text { staff. }\end{array}$ \\
\hline $\begin{array}{l}\text { European Social } \\
\text { (ESAN) }\end{array}$ & 1991 & Yes & $\begin{array}{l}\text { Horizontal mandate with specialisms in } \\
\text { social, human rights and development } \\
\text { fields. Founded by UK and French national } \\
\text { councils for voluntary organisations, } \\
\text { members in 17 countries. Social Platform } \\
\text { member. }\end{array}$ \\
\hline $\begin{array}{l}\text { Permanent Forum of } \\
\text { Society }\end{array}$ & 1995 & No & $\begin{array}{l}\text { Federalist outlook. Active on issues of } \\
\text { citizenship, participatory democracy, and } \\
\text { fundamental rights. Limited membership } \\
\text { base. }\end{array}$ \\
\hline
\end{tabular}

Sources: Organisation websites

The Social Platform was initially created as a joint initiative of DG EMPL and the Chair of the Employment and Social Affairs Committee of the European Parliament in 1995 to pursue a 'Civil Dialogue' for input legitimacy with civil society, drawing a parallel with the 'social dialogue' for producer organisations. Its early work was geared at a wide scale mobilisation of citizen interests at EU level to this end, but progressively developed as an organisation into an institutional interlocutor for EU political institutions (Geyer, 2001; Smismans, 2003; Cullen, 2005). These have included bi-annual 'civil dialogue summits' with DG EMPL, organising NGO input into the Convention on the Future of Europe (Cullen, 2005) and in meetings of the informal Council of Social Affairs and Employment (Alhadeff, 2003). It has previously sought a system of accreditation for EU interest groups on the basis of 'representativeness' in the knowledge that such a system would leave it at the top of the tree, arguing for the highest level of financial support to be reserved for it (Cullen, 2005). Seeking to distinguish itself from other organisations, the Social Platform has developed criteria of representativeness which need to apply as criteria for other organisations to join it as a member: 
The network or federation must be composed of organisations (not individuals) in at least the absolute majority of the EU Member States. The network or federation must be established as a not-for-profit and non-governmental organisation in one of the EU member states. The majority of the organisation's membership must themselves be legally established, not-for-profit and non-governmental. The network or federation must be active in the social sector, working to promote the general interest and contributing to social cohesion. The network or federation must demonstrate its representativity and that it is structured and managed in a democratic way, it is run by an elected body, whose decisions and membership must not be subject to approval by any extraneous body (Social Platform, 2010, p.8).

This criterion sets the organisation apart from its competitors, clearly defining its niche as representativity. In its quest for a civil dialogue in which it would play a leading role, it has complained that 'civil society organisations do not currently take part in structured dialogue and yet it is these groups who are directly affected by European decisions' (Social Platform, 2016, my emphasis), thus seemingly losing sight of citizens. By contrast, the Permanent Forum of Civil Society is highly active on European citizenship and participatory democracy, with individuals as members. Similarly, ECAS is a leading organisation in the citizen's rights domain based around its pursuit of citizenship, but whose voice does not depend upon its diversely constituted membership list. It was founded by an 'interest group entrepreneur' with substantial experience on the Brussels scene who saw a 'niche' gap in the advocacy market, much in the way in which specific business organisations have also emerged and differentiated themselves from one another (Chapter 4). There is space for them all because they all do something different, dependent upon each carving out its own distinctive niche. These differences are apparent in their approaches to particular causes. For instance, a 'Citizen's Initiative' has been a natural cause for ECAS to champion. And the leadership which ECAS (and the Permanent Forum) has given to a European 'compact' to govern, inter alia, standards of consultation with political institutions, draws upon the experiences of its widely drawn membership base, but it makes no pretence to 'representativeness'. For such organisations, their raison d'être is rather to advocate a 'cause' (i.e. they are 'what', rather than 'who' organisations), and the application of any instrument of representativity as access criteria by EU institutions would have a deleterious impact upon their work and status. This is discussed further in Chapter 8. 


\section{The European Citizens' I nitiative}

The European Citizens' Initiative (ECl) was introduced by the Lisbon Treaty as a direct participatory measure for citizens, and thus entirely set aside from a 'civil dialogue' between NGOs and EU institution. A 'Citizens Committee', comprised of 7 individuals from 7 different member states, can launch an initiative on a topic covered by the EU Treaties, and, once registered, campaign for the threshold of 1 million signatures from at least 7 member states (weighted for size) collected within 12 months. Once signatures have been verified, the Commission has three months to consider its response, presented at a hearing in the European Parliament. There is, however, no element of mandation, and thus the measure has been conceived as an agenda-setting device, rather than a direct democracy measure. Over 50 campaigns have been launched, introducing diverse topics to EU politics for the first time, such as calls for the legalisation of cannabis, for an unconditional basic income, and criminalisation of Ecocide. As direct democracy campaigners estimate it takes five conversations to convert to a single signature, the effect of campaigning magnifies the way in which EU agendas are brought to the member states. This ratio is partly due to the requirements of signatories to provide campaigners with personal data for the purposes of verification, including an address and, in most member states, a passport or national identification number. To date, around two-thirds of signatures have been collected online (European Parliament Research Service, 2015), but in order to satisfy the technical requirements for data protection the design of an online system is particularly onerous for campaigners, whilst the use of a 'captcha' can deter would-be signatorees. Only three campaigns registered to date have reached the 1 million threshold within 12 months, each launched by organisations with an established network (a trade union, the Catholic church, and animal rights organisations), with only one of these achieving a partial policy success. Thus, the value of the mechanism is mostly to raise lesser known issues, and the process of campaigning for signatures. Nonetheless, the measure has enthused a young group of activists who enjoy campaigning, mostly fresh from student politics at university with experience of studying in another member state, and who are mostly distinct from the established world of Brussels NGOs. Some of these have used their networks to take campaigns into some of the new member states (Greenwood and Tuokko, 2016), introducing some national collaborators to EU politics for the first time.

\section{The Funding of NGOs}

The Commission has been a significant source of funding for citizen interest groups organised at EU level. Their purpose in doing so has been to ensure the presence of checks 
and balances in the ways in which demands are brought to the political system, and to perform democratic functions (such as accountability pressures) because of the relative weaknesses of other mechanisms (low levels of public engagement, no EU wide media or mass political parties, etc.). Funding is one of a number of mechanisms designed to empower NGOs. Virtually all such groups (Greenpeace and Amnesty International are notable exceptions) are beneficiaries of EU funding regimes, such that most NGOs at EU level get much of their funding from EU institutions.

It is difficult to establish a precise figure for the total extent of funding by EU institutions of NGOs, with estimates from Commission sources varying from €1-2 billion. Thus, the Commission discussion paper of 2000 issued in the name of President Barroso and VicePresident Kinnock, recorded that

At present it is estimated that over 1,000 million a year is allocated to NGO projects directly by the Commission, the major part in the field of external relations for development co-operation, human rights, democracy programmes, and in particular, humanitarian aid (on average $€ 400$ million). Other important allocations are in the social (approximately $€ 70$ million), educational (approximately $€ 50$ million) and environment sectors within the EU. Several hundred NGOs in Europe and worldwide are receiving funds from the EU (European Commission 2000b).

The Commissioner announcing the European Transparency Initiative in 2005 recorded that 'annually the Commission channels over 2 billion euro to developing countries through NGO's.' (Kallas, 2005, p.6). Most policy areas have budget lines for the support of NGOs, and some citizen groups organised at EU level receive most of their funding from EU political institutions. Two types of funding are possible; action grants (for specific projects, etc.) and operating grants (for core establishment funding). The Financial Transparency System is an online searchable database established by the European Commission of grant awards, and the Transparency Register involves disclosure of sources of income. Table 6.3 provides illustrative data for some organisations which appear in both information sources: 
Table 6.3: EU Funding of principal EU NGOs

\begin{tabular}{|c|c|c|c|}
\hline Organisation & $\begin{array}{l}\text { Funding } \\
\text { year }\end{array}$ & $\begin{array}{l}\text { Financial } \\
\text { Transparency } \\
\text { Database } \\
\text { (year if } \\
\text { different to } \\
\text { column 2) }\end{array}$ & $\begin{array}{l}\text { Self-disclosure by } \\
\text { organisation on } \\
\text { European Transparency } \\
\text { Register of amount of } \\
\text { EU funding/ proportion } \\
\text { of income }\end{array}$ \\
\hline Culture Action Europe & 2014 & $€ 2,166,000$ & $€ 220,000 / 55 \%$ \\
\hline $\begin{array}{l}\text { European Anti-Poverty } \\
\text { Network (EAPN) }\end{array}$ & 2014 & $€ 2,246,953$ & $€ 1,725,351 / 84 \%$ \\
\hline $\begin{array}{l}\text { European Citizen Action } \\
\text { Service (ECAS) }\end{array}$ & 2014 & $€ 2,566,062$ & $€ 2,525,732 / 99 \%$ \\
\hline $\begin{array}{l}\text { European Consumers } \\
\text { Organisation (BEUC) }\end{array}$ & 2014 & $€ 4,726,327$ & $€ 2,553,289 / 52 \%$ \\
\hline $\begin{array}{l}\text { European Council for Non- } \\
\text { Profit } \quad \text { Organisations } \\
\text { (CEDAG) }\end{array}$ & 2015 & $€ 5,000$ & $€ 0$ \\
\hline $\begin{array}{l}\text { European Environmental } \\
\text { Bureau (EEB) }\end{array}$ & 2015 & $€ 48,355$ & $€ 1,313,579 / 40 \%$ \\
\hline $\begin{array}{l}\text { European NGO } \\
\text { Confederation for Relief and } \\
\text { Development (CONCORD) }\end{array}$ & 2015 & $€ 864,458$ & $€ 700,000 / 55 \%$ \\
\hline $\begin{array}{l}\text { European Public Health } \\
\text { Alliance (EPHA) }\end{array}$ & 2015 & $€ 2,175,873$ & $€ 544,247 / 67 \%$ \\
\hline $\begin{array}{l}\text { European Social Action } \\
\text { Network (ESAN) }\end{array}$ & 2014 & $\mathrm{n} / \mathrm{a}$ & $€ 0$ \\
\hline $\begin{array}{l}\text { European Women's Lobby } \\
\text { (EWL) }\end{array}$ & 2014 & $\mathrm{n} / \mathrm{a}$ & $€ 846,446 / 78 \%$ \\
\hline $\begin{array}{l}\text { European } \text { Youth } \\
\text { (EYF) }\end{array}$ & 2015 & $€ 6,113,088$ & $€ 2,725,522 / 96 \%$ \\
\hline $\begin{array}{l}\text { Friends of the Earth Europe } \\
\text { (FOEE) }\end{array}$ & 2014 & $€ 813,721$ & $€ 3,050,338 / 63 \%$ \\
\hline $\begin{array}{l}\text { Platform of European Social } \\
\text { NGOs }\end{array}$ & 2014 & $€ 600,000$ & $€ 598,785 / 84 \%$ \\
\hline
\end{tabular}




\begin{tabular}{|l|l|l|l|}
\hline $\begin{array}{l}\text { World Wide Fund for Nature } \\
\text { (WWF) European Policy } \\
\text { Programme }\end{array}$ & n/a & $€ 588,127 / 16 \%$ \\
\hline Average EU Funding & & & $56 \%$ \\
\hline
\end{tabular}

Sources: European Financial Transparency Initiative, 2016; European Transparency Register, 2016

The above figures provide indicate the staff resources of such organisations. WWF has 33 staff, and therefore comparable with the staffing levels of the principal EU business associations (Chapter 4). Additionally, such international NGO brands can draw upon the resources of branch offices based in other European countries, and upon those of some of its members for technical input. Outside of these global organisations, the organisation with the highest number of staff is the European Youth Forum, with 28 staff.

The extent of EU funding raises questions about the independence of citizen interest groups. The view from leading organisations in the sector is that funding from EU political institutions is a source of independence (from needing to seek funds from business) rather than dependence, rather like state funding of political parties. Sanchez Salgado found no evidence that funding constrains NGOs; whilst there are statements that the recipients must not follow goals incompatible with the Treaties, it had no means of monitoring the detail of this in implementation, allowing anti-globalisation organisations such as ATTAC to access EU funding (Sanchez Salgado, 2014). The degree of critical engagement by such groups with EU political institutions, apparent throughout responses to proposed policy initiatives, suggests that such organisations may not feel specifically compromised; the Social Platform, receiving over $80 \%$ of its funds from EU institutions, once famously pronounced in a press release that 'Mr Barroso, you killed the European Dream' (Fazi and Smith, 2006, p.20). Nonetheless, there is a likely subliminal general effect that those whose livelihood depends upon such funding will tend to have a generally positive outlook to 'project Europe'. Some of the global NGOs, such as Greenpeace and Amnesty International, have taken the option not to seek EU funding. Some authors see the receipt of funding as bringing with it a set of perceptions about obligations, including a requirement to participate in (relatively inconclusive) open consultation exercises, which then helps to secure access to a second tier of more restricted participatory for a (Mahoney, 2004; Kohler Koch, 2012). The implications of this are considered further in Chapter 8. 
There has also been a diversification of funding sources among the EU NGO community in recent years. These include the use of other established charities, such as Oxfam and Christian Aid, and foundations with funds historically derived from business wealth, such as the Adessium Foundation, the Joseph Rowntree Trust, the Sigrid Rausing Trust, the OAK foundation, the Sir James Goldsmith Foundation, and the Isvara Foundation. The latter is unusual in that its funds derive from the wealthy Chairman (Ayman Jallad) of a Lebanese business importing and distributing 'Caterpillar' brand tractors, with funds distributed to beneficiaries through a Swiss bank account (Deighton, 2011; Zadek, 2011). A number of 'left to outside left' leaning organisations active at EU level have drawn upon a common pool of foundation sources, indicating the high degree of network overlap between them. These ties are strengthened by their presence in an NGO 'eco-house', purpose renovated premises a short walk away from the European Parliament building in Brussels, where around 50 organisations share back-office facilities in the Mundo-B building, a 'palace of protest' with an atmosphere of a 'well-run students union' (Ariès and Panichi, 2015). The occupants bridge NGOs with professionalised social movement organisations. Another Mundo facility, the Mundo-J building, is closer still to the European Parliament, accommodating 30 organisations mainly related to Youth and Education, as well as Transparency International. Still closer to the EP, in the main Brussels property hotspot, is another ethical fund house building accommodating the Social Platform and some of its members. 
Figure 6.1: NGO clusters around the European Parliament in the Brussels property hotspot

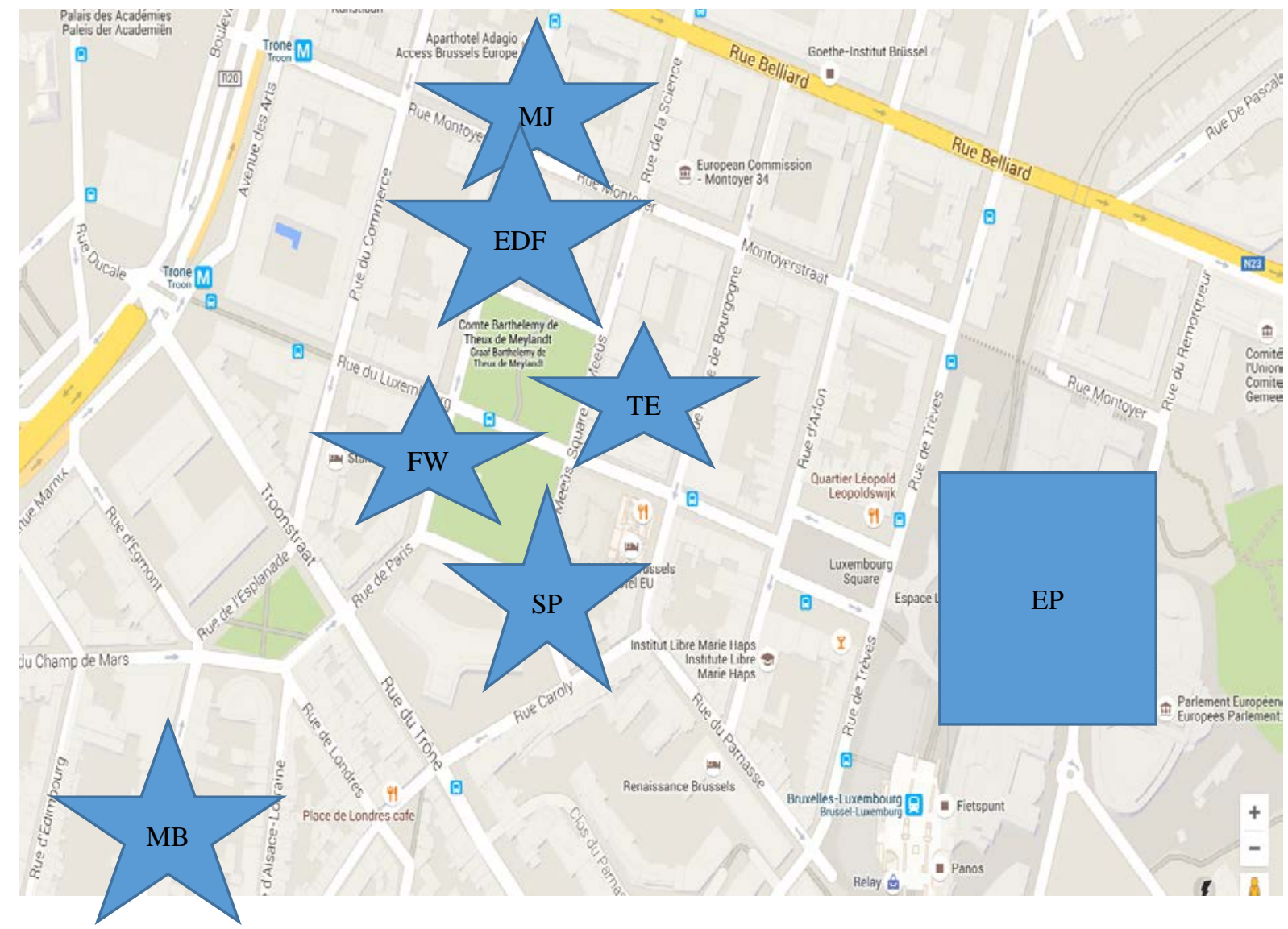

Key:

EDF: European Disability Forum

EP: European Parliament

FW: Finance Watch

MB: Mundo B

MJ : Mundo J

SP: Social Platform

TE: Transport \& Environment

These realities mean that EU NGOs now have the resources and capabilities to move 'beyond victimhood'. Self-positioning as victims can effectively play upon sensitivities that political institutions only listen to one side of the argument. But the EU NGO community now has the resources, the maturity of establishment, and the institutional means, to 
move beyond access to participation. Chapter 2 provided an example of this through the participation of environmental and consumer organisations in technical standard setting bodies, funded partly by EU institutions. Participatory mechanisms are also described in the sections which follow, and in Chapter 8 where EU procedures designed to equip NGOs to participate as democratic agents (e.g. of accountability) are detailed.

\section{Historic Landmarks in the Development of EU Citizen Interest Representation}

Consumer groups were the first citizen interest organisations at EU level, reflecting the focus of the European Economic Community, and quickly emerged in the years immediately following the Treaty of Rome. This wave was followed by groups representing world development and human rights concerns. Both sets of groups were heavily institutionalised in dialogues with the European Commission. A formal dialogue structure between consumer interests and the Commission dates from 1961, and has continued (subject to a number of reforms), to the present day. Since the mid 1970s, a Liaison Committee with Development NGOs (later CONCORD) embraced an elaborate structure of organisations, acting as an institutionalised channel for dialogue with the European Commission. Amnesty International arrived on the scene in the mid 1980s, with other groups in the domain arriving following the establishment of EU competencies in the 1992 Treaty on European Union. Animal rights groups were also an early citizen group on the EU scene. The European Environmental Bureau was established in 1974 as an umbrella body and institutional interlocutor for (and heavily financed by) the Commission, and remained the sole environmental public interest group in Brussels until the late 1980s. Those who came in the late 1980s, such as Greenpeace, Friends of the Earth and the World Wide Fund for Nature, established outreach offices as co-ordinating devices for wider movements to address EU political decision making.

A 1986 report in the European Parliament (Fontaine Report), leading to a subsequent EP resolution, put the 'third sector' of social and civic organisations on the EU policy agenda, recording that

Europe needs inspiration to take a further step towards its destiny as a Community. Nonprofit organisations are an opportunity to be taken in this respect. Inertia must be overcome and this opportunity must be boldly seized (Kendall and Fraisse, 2005, p. 283).

Most of the action followed during and beyond the TEU period, when a wave of 
organisations oriented towards poverty, disability, public health, voluntary sector provision, justice/home affairs types of issues, came to Brussels. The Treaty on European Union included a landmark declaration, Declaration 23, stating the importance... of cooperation between the European Community and charitable associations and foundations as institutions responsible for welfare establishments and services' (European Commission, 2006a). Despite this, many such organisations operated at the fringes of Treaty competencies, clustering around the emerging social programmes and initiatives coming out of DG V, until the insertion of an Article in the 1997 Amsterdam Treaty opened the gates for the development of social policy beyond labour market measures. Many of these groups also have their origins or spurts of significant development dating from major Commission White Papers of the early to mid-1990s, such as those on Growth, Competitiveness and Employment (1993) and European Social Policy (1994), or initiatives such as action programmes or mainstreaming (Chapter 5 ), which resulted in landmark social action programmes for the remaining years of the 1990s. The Social Platform's organisation of two large 'social forums' in search of 'civil dialogue' during this period were also landmarks, helping to develop the social platform's leadership role for EU civil society organisations. A new budget line for NGOs to pursue civil dialogue in 1997 supported these activities.

From the side of EU political institutions, DG EMPL was a clear leader in these 'social policy' initiatives, whereas the leadership for another set of related, parallel initiatives running at the time in the social economy field was provided by a unit within a now defunct service of the European Commission, DG XXIII (now incorporated within DG Enterprise). Thus unit, together with CEDAG, proposed an ultimately unsuccessful mission for a European Association Statute, seeking a legal status for EU organisations in the wider frame of democratic legitimacy (Kendall and Fraisse, 2005). In 1997 the unit launched a Commission Communication on 'promoting the role of voluntary organisations and foundations in Europe' which argued that

voluntary organisations and foundations foster a sense of solidarity and citizenship, and provide the essential underpinnings of our democracy. In the light of the challenges now facing the European Community, these functions have never been more vital (European Commission, 1997, p.5).

This claim was followed up by the 2000 Commission Discussion Paper 'The Commission and NGOs', which argued that 'NGOs can make a contribution to fostering a more 
participatory democracy both within the EU and beyond' (European Commission, 2000, p.4). This thinking came downstream in the White Paper on Governance, aimed at structuring a system of participatory democracy as a wider solution to democratic legitimacy, and is the subject of extensive analysis in Chapter 8. In acting as a catalyst for the creation of a procedural framework for a systematic engagement with civil society, the White Paper followed up an agenda first set by the 1992 Sutherland Report (Sutherland, 1992).

'Democratic legitimacy' was also a catalyst for the creation in the late 1990s of a structured dialogue by DG Trade with civil society in the formulation of external trade policy, and a direct response to the issues raised by the 'Battle of Seattle.' The dialogue embraces 600 organisations across the spectrum of civil society (spanning producer and citizen interests), structured through 14 organisations elected by civil society, and provides funding to allow the participation of organisations based outside Brussels.

The 'Lisbon agenda' has been another development agent for civil society organisations of all kinds, extending opportunities beyond those organised at EU level for EU engagement. Clause 38 of the original European Council 2000 declaration launching the Lisbon process states that the social partners and civil society will be involved using various forms of partnership'. Objective 4 of the distinctive Open Method of Coordination (OMC) inclusion process is to 'mobilise all relevant actors'. Such relevant actors are explicitly envisaged as organised groups acting as representatives of, and proxies for, wider civil society. There have been mixed reports of success in engaging the diversity of organised civil society in the process (European Economic and Social Committee, 2004; Kok, 2004), but on the credit side the European Anti-Poverty Network (EAPN) and the Social Platform have been closely engaged with the design and monitoring of the process. EAPN is highly institutionalised in DG EMPL (Bauer, 2002) and receives a significant strand of its EU funding for the purpose of promoting the participation and dialogue central to the OMC inclusion process (Armstrong, 2003). There is also a 'revolving door' of staff between EAPN and DG EMPL (Sanchez Salgado, 2014). Groups such as EAPN have been progressively drawn into the EES through its leading role on behalf of EU social policy NGOs in the Social Inclusion Strategy (Armstrong, 2003; De La Porte \& Nanz, 2004).

These historical landmarks help to explain the role of citizen groups in the EU policy process of today, and their high degree of institutionalisation. They are brought to life by the detail of segments of citizen interest representation, starting with the interests widely 
seen as having the greatest impact at EU level, environmental NGOs.

\section{Environmental I nterests}

As successive Earth Summits have revealed, the EU's environmental policies are the most advanced in the world. This reflects the reality that environmental issues are a central public interest concern throughout (particularly, northern) member states, and are highly politicised. Consumer behaviour displays significant environmental motives, and business has adopted significant aspects of the environmental agenda in response. Germanic Europe has concerns about acid rain, there are regionally acute issues about flooding and rising sea levels, and pollutants dispersed into the long, slow flowing Rhine where dispersal takes time, contribute to agendas of public concern. Eurobarometer surveys have repeatedly shown the popularity of the European level to tackle environmental problems based on the premise that 'pollution is no respecter of international boundaries.'

EU environmental action can be traced back to a 'landmark' summit held in Stockholm in 1972 which gave rise to the first of a series of 'environmental action programmes.' The seventh of these runs from 2013-2020. Beyond these are single market related issues, where high environmental protection countries in Germanic Europe have sought to 'export' their high cost production conditions to lower protection countries, on the whole successfully. The Single European Market was the first formal recognition of environmental policy in European policy-making, extended by the TEU to the use of QMV and the addition of the precautionary principle. Co-decision powers now apply to most areas of environmental policy. The single market enabled countries to proceed with high standards of environmental protection than adopted at the EU level, provided they were compatible with the treaties. A landmark ruling in the Court of Justice in 1988, the Danish bottles case (C302/86 Commission v Denmark 1988, ECOR4607 OR 19891 CMLR 619), took environmental protection beyond single market issues of a level playing field, enabling measures primarily designed for environmental protection even if they constituted a trade barrier. The number of environmental directives in the period from 1989-91 exceeded those of the preceding twenty years (Young, 1995). These were followed by the Environmental Fifth Action Programme (1993-2000), which gave a quantum leap to environmental policy with its motto 'towards sustainable development', a principle incorporated into the 1997 Amsterdam Treaty. Those years also saw the establishment 
of the European Environmental Agency (EEA) in Copenhagen, the fourth enlargement of the EU (adding high standard countries to EU policy making), and environmental assessment policy mainstreaming throughout Commission policy making and in external aid, trade and international relations. In 1998, the EU signed the Arrhus Convention on citizens' rights in environmental matters, guaranteeing rights of access to information, public participation in decision making, and access to justice in environmental matters. In 2001, the Gothenburg European Council agreed upon a Sustainable Development Strategy for Europe, adding the Environmental Pillar to Economic and Social Pillars as a core component of the Lisbon Strategy, and signalling the final arrival of environmental agendas as core to EU policy-making.

These factors raise the issue as to the extent to which environmental interest groups have been a driver of EU public policy in environmental protection, or largely operate within a set of favourable circumstances more shaped by other influences. This question can be addressed following an assessment of the population of groups and their action. The groups themselves tend to see their influences in terms of agenda setting, of which a significant recent example concerns the REACH dossier (Regulation, Evaluation and Authorisation of Chemicals). Whilst this is an item of EU legislation, it has a significant global impact in that anyone seeking to sell chemicals in Europe has to conform with it. The basic principle is that the responsibility lies with the producer to scientifically demonstrate to an independent regulatory agency that their products are safe, and in the case of reasonable scientific doubt the 'precautionary principle' (a presumption of danger) prevails. Tony Long, European Policy Director of the WWF European Policy Office since 1989, reflected that

in $\mathrm{REACH}$, without the persistent and very strong lobbying from the environmental NGOs, it would not have been possible for the Environment Commissioner to put forward such a proposal with such consequences for industry (Long \& Lorinczi, 2009, p.176).

This extract emphasises the agenda-setting role of environmental NGOs, which is further highlighted by a dilution of the final legislation when compared to the original version. Nonetheless, complaints by opposing sets of stakeholders that the regulation was too tough or too soft allows EU political institutions to claim that the balance, achieved after significant consensus seeking within and between the Commission, Parliament, and Council, is about right, and as such certainly reflects a typical outcome of EU public policy making. 
Beyond agenda setting, environmental groups are also well equipped to undertaking a 'watchdog' role (Long and Lorinczi, 2009). The Water Framework Directive gives NGOs a specific monitoring and guidance role, and environmental NGOs are involved in 50 consultative groups of the European Commission (Fazi and Smith, 2006). They are well capable of engaging policy making at a scientific level, drawing upon EU policy offices which are among the best staffed of citizen interest groups, a highly committed network of volunteers, and in the cases of Greenpeace, WWF and Friends of the Earth, the resources of global movements. As is described below, a core network of environmental organisations also co-ordinate their resources for EU related purposes. Together, these enable the environment movement to match the resources which collective business organisations apportion to the environmental dimensions of their activities. For instance, Long et al record how traditional energy source companies and some of the main business associations such as UNICE, ERT and Eurelectric were 'not really on the ball' about a significant detail with potentially major ramifications affecting their interests, and failed to give it sufficient priority or engage in much active lobbying (Long et al, 2002). These factors suggest that earlier eras in which business lobbying on environmental issues swamped the efforts of others (Butt Philip and Porter, 1995) have now passed. Nonetheless, where necessary business has significant resources to draw upon for the purposes of environmental policy making. The downstream oil industry has a specialist bureau, the Oil Companies European Organisation for Environmental and Health Protection (CONCAWE), attached to the Brussels offices of its trade association, Fuels Europe.

As well as conflict can be found degrees of collaboration between business and light green' interest groups, particularly where there is a coincidence of interests such as renewables, or where one segment of business is seeking to impose higher production costs onto another. At a more permanent, cross sectoral level, the European Partners for the Environment (EPE), a Commission initiated structure under the Environmental Vth Action Programme (Lenschow, 1996; 1999), brings together some NGOs (such as WWF and the EEB) with business (such as DOW Europe and Hydro) and trade unions (including ETUC) and public (mainly local) authorities, 'to improve cross-sectoral collaboration and joint initiatives to align business, capital, markets and society more closely with the sustainability agenda' (EPE, 2016) 
Some of this mutual learning can be found downstream in industry organised voluntary environmental schemes to promote good practice, such as the issue of certificates of good environmental practice. The Marine Stewardship Council, for instance, was a joint initiative of Birds Eye processed fish foods (then a Unilever Brand) and WWF, involving the certification that fish had been drawn from sustainable stocks. Initiatives such as these are geared towards showing how good environmental practice can also be good business sense, through meeting consumer demand, providing competitive advantage and good positioning, and reducing overheads (Ruzza, 2000). For business organisations, an alliance with an environmental NGO is highly prized, because of the general need for alliance making in a consensus orientated decision making system, and because of the strength of environmental protection sentiment in Europe. For these reasons, a European public affairs manager of one leading US multinational consumer brand reports spending more time talking to NGOs than to EU institutions. Nonetheless, achieving an issue specific business-green alliance in detail is not easy, and often once achieved, is somewhat unstable. There are more examples of participation by 'light green' NGOs such as the EEB and WWF. The latter purposefully tries to lend its name to projects involving business organisations which have tangible benefits for the environment. EEB has entered into alliances with Orgalime, the EU engineering association, and with the IT and consumer electronics associations, about practical collection targets in the framework of the European Waste from Electronic Equipment (WEE) Directives. The risk of entering into such alliances is an apparent compromise to 'ideological purity'. The latter position may be more informed by the need to maintain membership levels and the funds the bring, and therefore a niche for some of the 'dark green' organisations is to undertake 'stunts' with high media visual appeal as a means of demonstrating to its members that the organisation concerned is active about the things which concern them in a 'protest business' (Jordan and Maloney, 1997). In practice, however, even 'dark green' organisations enter into issue specific alliances with business interests on the Brussels scene.

As well as voluntary initiatives among producers, statutory framework initiatives to which the environmental movement has contributed have reinforced and contributed towards changes in consumer behaviour. And as well as specific interventions over policy measures, the key contribution of Environmental public interest groups, at EU and other levels, are the influences they have contributed to the belief systems of policy makers and of business and consumers.

Not long after establishing an office in Brussels, the Director of the WWF European 
Policy Office (WWF-EPO) reflected that 'in general the environmental organisations are unable to exercise power' (Long, 1995, p. 678). Eight years later, he commented that 'all the talk in Brussels these days about the role of 'civil society' and the need to consult more widely is not just words... whatever the reason, civil society is becoming recognised as the missing element' (Davis, 2003, p. 66). By 2009, he was emphasising the leadership given by environmental groups to the wider NGO community, including their ability to bring in much broader 'policy clusters' of coalition partners to key environmental campaigns (Long and Lörinczi, 2009). Reflecting on the history of environmental NGOs at EU level from their early days, he records that

Now, after several decades of expansion, the (one time) new market entrant is seen by some as possibly part of a 'lobbying oligopoly' (Long and Lörinczi, 2009, p.183).

For these authors, environmental NGOs have been able to progress beyond their traditional strengths of agenda-setting, but a key question remains how capable they are of competing with business interests during other stages of the policy process. One of the dimensions of this concerns their ability to participate throughout detailed stages of the passage of legislation, of which their resource base is a key part.

Environmental Citizen Interest Groups

Table 6.4 details the Brussels offices of the 'Group of Ten' (Green10) environmental NGOs, a loose but co-ordinated network 'of the ten leading environmental NGOs active at EU level' who 'coordinate joint responses and recommendations to EU decision makers' (Green10, 2006, p.3). 
Table 6. 4 Green10 Transparency Register declarations

\begin{tabular}{|l|l|l|l|l|l|l|l|}
\hline Organisation & $\begin{array}{l}\text { Financ } \\
\text { ial } \\
\text { Year }\end{array}$ & $\begin{array}{l}\text { Total } \\
\text { budget } €\end{array}$ & $\begin{array}{l}\text { TR } \\
\text { activity } \\
\text { spending } \\
\boldsymbol{\ell}^{\mathbf{1}}\end{array}$ & $\begin{array}{l}\text { EU } \\
\text { funding } \\
\boldsymbol{€}\end{array}$ & $\begin{array}{l}\text { N. } \\
\text { staff }\end{array}$ & $\begin{array}{l}\text { FTE } \\
\text { staff }\end{array}$ & $\begin{array}{l}\text { EP } \\
\text { passes }\end{array}$ \\
\hline Birdlife Europe & 2014 & $1,222,760$ & $1-1.25 \mathrm{~m}$ & 316,230 & 18 & 18 & 5 \\
\hline CEE Bankwatch & 2014 & $1,745,897$ & $300-399 \mathrm{k}$ & $1,194,195$ & 4 & 2.8 & 2 \\
\hline $\begin{array}{l}\text { Climate Action } \\
\text { Network }\end{array}$ & 2015 & $1,240,655$ & $800-899 \mathrm{k}$ & 262,762 & 19 & 15.8 & 11 \\
\hline $\begin{array}{l}\text { European Envt. } \\
\text { Bureau }\end{array}$ & 2015 & $3,266,046$ & $3.35-3.5 \mathrm{~m}$ & 1,113765 & 17 & 16.8 & 11 \\
\hline $\begin{array}{l}\text { Friends of the } \\
\text { Earth Europe }\end{array}$ & 2014 & $4,830,196$ & 830,736 & $2,610,891$ & 15 & 6.5 & 10 \\
\hline $\begin{array}{l}\text { Greenpeace } \\
\text { European Unit }\end{array}$ & 2015 & $1,625,727$ & 952,627 & 0 & 11 & 7.2 & 11 \\
\hline $\begin{array}{l}\text { Health \& } \\
\text { Environment } \\
\text { Alliance }\end{array}$ & $2014 / 1$ & 779,086 & $100-199 \mathrm{k}$ & 356158 & 5 & 2.5 & 6 \\
\hline $\begin{array}{l}\text { Naturefriends } \\
\text { intl. }\end{array}$ & 2014 & 828,978 & Below 10k & 199,809 & 0.5 & 2 & 0 \\
\hline $\begin{array}{l}\text { Transport \& } \\
\text { Envt. }\end{array}$ & 2015 & $3,721,577$ & $3.5-3.75 \mathrm{~m}$ & 0 & 19.2 & 25 & 17 \\
\hline $\begin{array}{l}\text { WWF EU Policy } \\
\text { office }\end{array}$ & $2014 / 1$ & $3,642,316$ & $2-2.25 \mathrm{~m}$ & 588,127 & 21.8 & 33 & 13 \\
\hline Total & 5 & $22,903,32$ & & $6,641,937$ & 130 & 129.6 & 86 \\
\hline
\end{tabular}

Source: Transparency Register

The Green10 estimates that its collective membership is over 20 million people (G10, 2010). The mass membership base of many of them, together with the skills acquired by European offices, enables them to combine institutional politics with traditional social movement activism. As is discussed later, groups such as Greenpeace, and Friends of the Earth, act as a bridge between the respective worlds of institutionalised Brussels NGOs, and radical social movement networks (Hadden, 2015).

In addition to the G10 are environmental NGOs outside of the network but with a Brussels office. These include a number of occupants of the Mundo-b building, as well as the EU Liaison Office of the Europe Regional Office of the International Union for Conservation of Nature (IUCN) (fourteen staff), and the European Cyclists' Federation. There are also a number of regionally based environmental organisations. Commission funding supports the work of 28 environmental NGOs (Kirchner, 2006). There are thus

\footnotetext{
${ }^{1}$ Reported in bands or as an absolute figure

${ }^{2}$ Full Time Equivalent
} 
around 150 staff working for environmental public interest groups based in Brussels alone, supplemented by the potential resources of other European offices of organisations, and countless supporters willing to contribute expertise and voluntary assistance. Greenpeace, for instance, claims to have access to over 1200 scientific environmental experts worldwide (Mazey and Richardson, 2005, p.116), making for an interesting comparison with those of the collective chemical industry $(4,000)$, described above. Participation at a level of detail, it seems, is possible for environmental NGOs throughout the policy process, rather than simply relying upon the strength of environmental sentiment to agenda-set issues.

Apart from some tensions surrounding the position of the EEB, described below, and some frictions arising from significant differences in style, relationships within the Green 10 are generally collaborative and well co-ordinated. They meet together every month for purposes of information swapping and co-ordination, periodically with the Cabinet of the Environment Commissioner and with the Director General of DG Environment, and, on an annual basis, with the President of the Commission. The Environment Commissioner has been known to turn up, unannounced, at meetings of the G10 (Long and Lorinczi, 2009). Most G10 members have excellent links throughout DG Environment, meet up in a variety of other fora, and get to share thinking. Co-ordination is particularly good between a core 'Gang of Four', comprising the EEB, FoE, WWF and Greenpeace, who commenced the network as 'G4' in 1990 (Long and Lorinczi, 2009). Most of the Green10 have competencies in matters affecting the environment across the range of their interests, with an informal and unwritten division of labour to enable the organisation with the natural specialism to take the lead on it. This division is not intended to be exclusive, in that most of the organisations undertake work on a core of related environmental issues. Long and Lorinczi have reflected that

NGOs might have an advantage over business groups in that NGOs find it easier to construct and maintain broad cross-national coalitions than do business interests who are essentially in competition with each other and who are differentially affected by EU regulation (Long and Lorinczi, 2009, p.177).

The Green10 claims that it

successfully lobbied the European Convention to retain existing Treaty commitments to sustainable development, environmental protection and the integration of environmental concerns into each EU policy area (G10, 2010). 
This claim once again raises the problematic issue of the extent to which environmental NGOs create policy outcomes, or act as contributory voices to outcomes which would have happened anyway. There is some confidence among leading G10 participants on this point, with Long and Lorinczi claiming that

A G10 letter to President Barroso in July 2005 was undoubtedly influential in saving the seven thematic strategies on the environment being proposed by Commissioner Dinas from disappearing off the Commission's agenda (Long and Lörinczi, 2009, p.175).

Once again, the power of EU environmental NGOs as agenda-setters is stressed by this reflection.

The organisational figurehead for the G10 is the EEB, as the first to be established in the field through the environmental services of the European Commission. As a confederation, it carries the usual advantages and disadvantages of breadth, much as the review of similarly structured business organisations (Chapter 4) demonstrated. This, along with the need for it to share its space alongside other environmental activists, have been the source of the organisation's principal difficulties. It's diverse membership includes the (UK) Woodland Trust, national branches of Friends of the Earth, Greenpeace and WWF, to the European Union Foundation for Landscape Architecture (EFLA) and the European Foundation for City Farms. Nonetheless, the EEB is a good network organisation for its members, and as an organisation in its own right is well networked with other environmental NGOs on the global stage. As an organisation geared to addressing the EU political institutions rather than a social movement, it has a wide-ranging set of institutional contacts. Consistent with its preference for EU level groups, the EEB has been used by the Commission as its main interlocutor across the range of environmental interests, and has institutionalised its presence across a range of advisory committee structures. It has an astonishingly symbiotic relationship with DG Environment, to the extent that Mazey and Richardson record that

one Commission official suggested to us that the task force which preceded the formation of DG (Environment) was originally so weak that it sought the support of the NGOs and mobilised and supported them in order to defend itself. He believed that without NGO support DG (Environment) might have died in its early years (Mazey and Richardson, 2005, p.115). 
Apart from meetings with the Presidents of the Commission and the Council, the EEB is a member of Commission delegations at Earth/Environmental Summits.

These strengths apart, the EEB has also had some problems of style. A past Chair of the EP Environment Committee once commented that 'instead of making it short and snappy they go in for awfully wearisome and hectoring briefings. Effective lobbying is about being selective with information' (Financial Times, 1994). Inevitably, its influence has been diluted since other environmental NGOs established Brussels offices, and the EEB has not always welcomed the leadership the latter have sometimes given on particular environmental issues.

The WWF, and the Birdlife International network, are similar in outlook to EEB in working primarily through institutionalised channels at EU level. Their strong resource bases also enable them to engage policy making at a highly technical scientific level. The WWF has something of an establishment image as the world's largest and best-established field based nature conservation organisation, and declares corporate sponsorship amongst the financial contributors to its European policy office. Alongside its 'cuddly panda' image and institutionalised links, its European office has self-consciously sought to position itself as a policy as well as advocacy oriented NGO (Long et al, 2002). Besides using its established channels in the national delegation offices in Brussels, it has resorted to the European Court of Justice system where necessary to ensure action is taken against member states for environmental violations of structural fund initiatives. It has also played an important whistle blowing role, such as providing the European Investment Bank and the Court of Auditors with video evidence of environmental violations arising from use of the structural funds in Spain (Long, 1995). In addition, it also makes use of its massmembership base through letter-writing campaigns, co-ordinating with the Swiss based Europe/Middle East regional office of WWF International (Graziano, 1999). Birdlife International also has a mass membership base, with one million members in the UK alone (Graziano, 1999), which it has used in EU politics. Like WWF, Birdlife also has the status, resources (with 100 staff based in the UK; Graziano, 1999), and establishment reputation to work institutionally.

Like WWF and Birdlife, Friends of the Earth and Greenpeace are also equipped to engage EU policy making at a technical level, through permanent resources and supporting scientists, and have the ability to turn science into politics through their mass mobilisation base when required. Not for the first time, Greenpeace has also been able to triumph politics over science, when its mass letter writing campaign over the drinking water 
directive helped achieve an EP amendment about pesticide limits which the Commission accepted despite the opinion of its own scientific advisor (Warleigh, 2000). Graziano records that WWF 'is quietly critical of Greenpeace and its confrontational tactics, whereas the WWF embraces a philosophy whose central tenet is reliance on solid scientific evidence' (Graziano, 1999, p.23).

Whereas WWF and Birdlife are 'light' green, FoE and Greenpeace are more 'medium to dark' green. Friends of the Earth Europe (FoEE) is a highly decentralised network of independent national environmental organisations across Europe. This degree of decentralisation means that some FoEE national organisations have activities well beyond the environmental domain into general left of mainstream political goals, and some of these are highly networked in 'alternatives' circles. Its EU office has concentrated more on institutional contacts with the Commission and the Parliament, where it has a reputation as a valuable contributor of information, than on seeking to mobilise the movement's grass roots base. This illustrates the tendency for radical social movements to become tamed over time as they engage, become incorporated in, and influenced by the routines of, institutional political decision making, despite one of its original motivations for coming to Brussels being the weakness and institutionalised nature of the EEB. At one point in the 1980s it sought to establish a rival cross-sectoral organisation to the EEB, seeking to attract direct-action-oriented groups, which the EEB diverted by proposing greater coordination with and between the 'Gang of Four'. As a highly decentralised movement, the Brussels office of Friends of the Earth is more self-sufficient than is Greenpeace, whose work is more shared between its offices in the member states. Greenpeace is perhaps the most geared to direct-action campaigns and boycotts, although it has also learnt how to interact with the European institutions. Greenpeace actively supplements the resources of its Brussels office with those from elsewhere, in that responsibility for discrete EU policy areas often lies with national offices. Thus, Greenpeace Austria and Greenpeace Switzerland, for instance, have held responsibility for work on infrastructural TransEuropean Networks, where these issues have high environmental impact and strong local mobilisation, with specialists in the Brussels office only for chemicals, climate, electricity, and biotechnology. The Brussels office plays a co-ordinating role between these.

Whilst the differences between the G10 organisations mean that they cannot always work together, the overall pattern tends to work well for environmental citizen interests. The G10 embrace ranges from the respectable and 'establishment-friendly' WWF and Birdlife to the more assertive, direct-action-oriented Greenpeace and Friends of the Earth. It encompasses the mass-membership power base of FoE and Greenpeace, and the 
institutionalised EEB, WWF and Birdlife. Styles vary too, such as the interpersonal contact style of Birdlife, and the informal and loosely co-ordinated, but effective, Climate Action Network (Rucht, 1993). The relationships between the Green10 are more harmonious than are many business coalitions, and contain some close alliances, helped by the occupation by five Green 10 members of the Mundo-b building in Brussels. Because most are operational outreach Brussels offices operating with a high degree of autonomy, rather than membership offices, they do not have to be overly concerned with internal platformbuilding, enabling them to respond quickly to issues.

With the exception of Greenpeace, all of these organisations have been commissioned by the European institutions for investigative work. They all have the technical and political ability to turn science into politics by influencing the ways in which issues are perceived and defined, to become part of the knowledge communities which drive policy making, and to engage public policy throughout the different stages of its formulation, implementation, and monitoring. And, crucially, they have helped shape not only the thinking of other policy actors such as the Commission and producer groups, but also member state preferences towards environmental protection policies. Former WWF-EPO Director Tony Long is reported to have responded with delight to a Commission Green Paper on Common Fisheries Policy Reform with the words 'it could have been written by WWF' (Scotland Europa, 2002, p.96).

Environmental NGOs have a natural ally in the shape of the EP, whose members are quick to take up concerns popular with their electorate. Surveys of 'lobbying effectiveness' among parliamentarians have in the past indicated that environmental groups were rated by MEPs as the most effective of all citizen interest groups (Burson Marsteller, 2001). However, a repeat survey conducted in 2009 found that NGOs had been overtaken as 'effective lobbyists' in the estimation of MEPs by business interests, and particularly in the energy domain (Burson Marsteller, 2009). This contrasts with an early and celebrated 'success' of environmental interests with the EP, the Bio-patenting Directive of 1995, where intense lobbying activity contributed to an atmosphere in which the Parliament, using its new powers for the first time, rejected completely an industry friendly Commission draft to permit the patenting of genetic modifications. Thus, attempts to locate a clear pattern over time as to the impact of environmental interests are somewhat problematic. The analysis of practitioners of an increasing ability over time to intervene in public policy making beyond agenda setting is difficult to test empirically because of the difficulty of isolating the impact of environmental interest groups from other issues, not 
least of which is the general strength of the environment in public sentiment and its corresponding strength as an issue within the mechanisms of representative democracy.

\section{Consumer I nterests}

The Consumer Programme 2014-2020 records the objective of

'A single market where citizens are well represented by professional consumer organisations whose capacity is built to meeting the challenge of today's economic environment.'

This mini revolution in EU consumer affairs in recent years lies in stark contrast to Grant's assessment of a decade earlier that EU consumer policy was largely symbolic, and that European consumer groups were largely outsiders (Grant, 1993). Whilst that assessment was not shared by all other commentators at the time, it is fair to say that consumer groups have not been the catalyst for the sea change. The principal change catalyst has been the wider agendas of output legitimacy (a search for popular support for the EU through the impact of its policies), and the high, crisis, politics resulting from food safety problems, such as those over BSE and poultry. This resulted in the establishment of the European Food Safety Authority (EFSA) in 2002, and the investment of responsibility in the European Commission for food safety along the entire food chain. Other safety crises, such as the discovery of phthalates in toys and infant equipment and their subsequent ban for use in this context, have also contributed to this development.

The search for output legitimacy issues include the high profile targeting of particular consumer price issues, such as differential cross border car prices, denied and late boarding of aircraft, and the abolition of roaming charges for mobile phones used in a cross border context. 'High politics' and a search for output legitimacy have done more to drive consumer policy to centre stage of the EU agenda than fifty years of continual effort by EU consumer organisations could. They have developed an agenda logic of their own, almost separate to that of wider consumer policy, following the discourse of 'consumer protection.' Elsewhere, consumer policy has largely been a story of incremental progression, and even potentially major catalysts such as mainstreaming and the Transatlantic Consumer Dialogue (TACD) have not lit the touch paper. This bears interesting comparison with more radical progression in the environmental domain, 
because they share similar starting points of Community action programmes (circa 1972), and some common development factors, including the embrace of the favourable 'citizen's first' discourse:

- Mainstreaming. Consumer policy was mainstreamed later (1997 Amsterdam Treaty; Article 153) than environmental policy (1992 TEU). Commission consumer policy papers continue to carry calls for more effective integration, contrasting sharply with the achievement of environmental policy (European Commission, 2006b).

- Institutional Development and Support. In contrast with a history of significant and increasing funding for environmental policy, the annual EU consumer policy budget has declined relative to 1990 . The environmental arena achieved DG status at a much earlier stage and has its own dedicated Directorate General, whereas consumer affairs only achieved DG status at a relatively late stage, and is incorporated as a junior partner within Directorate Generals with a wider remit (Justice and Consumers, DG JUST; Health and Food Safety, DG SANTE). There is around four times the level of support reserved for EU Environmental NGOs compared with consumer NGOs, and there has been no growth in funding for consumer NGOs in more than a decade. Consumer/Commission liaison fora have not progressed beyond dialogue and advisory status in over 40 years of operation. Consumer policy is somewhat submerged in a Council which also covers employment, social policy and health, a re-organisation decision taken without any prior consultation of consumer representatives (BEUC, 2002a). Nonetheless, DG JUST has witnessed substantial development of instruments with which to engage with civil society organisations in recent years, and in particular with the development of Platforms in which companies have made public pledges which have the effect of advancing the consumer and health policy fields (Chapter 4). Nonetheless, the environment has had a 'social dialogue' type mechanism for some time in the form of the European Partners for the Environment.

- Different single market dynamics. Both areas acquired a firm legal basis for Europeanlevel actions as domains requiring action parallel to the single market and the use of QMV. Whilst environmental policy took off around the time of the single market programme and has enjoyed some radical development landmarks since, the single market was no radical launch paid for consumer policy, whose development has been more incremental and more dependent upon uneven crisis points. In environmental policy, progress has been made by 'leader countries' seeking to export their high cost production conditions to 'laggard countries' via single market measures. In consumer 
policy, the market advantage of high protection in consumer goods outweighed the competitive losses of higher production costs, giving leader countries the incentive to keep their market advantage to themselves (Young, 1995).

- Focus. Consumer behaviour is more driven by the sharper focus of green considerations, whereas the constitution of a 'consumer' interest is more elusive. Consumer organisations have borrowed the discourse of environmental groups. Alliances between environmental and consumer groups have been driven more by environmental issues, such as the European Campaign for Clean Air, which brought together consumer, environmental and public health organisations with a 'European Clean Air Campaign' to lobby for strict automobile standards (Webster, 1998; see also Young and Wallace, 2000).

- Responsible Agents. While both agendas involve socialising the message 'it's good commercial sense for business', the construction of accompanying measures to enable and build consumer confidence in making cross-border transactions involves public authorities to build infrastructures rather than action that is within the gift of business to take. These infrastructures involve considerable transaction costs. Whilst the adoption of standard currency measures ( $€$, metrification and labelling) has made cross border transaction comparisons easier and some progress in reducing differentials has been made, variations are still considerable, and some sectors continue to confront consumers with trade barriers. Consumer and citizen organisations have helped the Commission to energetically confront these through 'whistle blowing'. The Commission has also supported from the consumer policy budget an EU wide out-of-court complaints network for cross border financial service issues, FIN-NET.

Differing degrees of centrality to business. Consumers engage the core operations of businesses in markets, and contesting business has been more difficult for consumer groups. Environmental agendas have been grafted on to business agendas by more mixed sources.

- Collective Action. Whilst the Green10 has grown, the number of pure consumer policy oriented organisations at EU level has shrunk to one (BEUC), and one concerned with input to technical standards bodies. BEUC is a confederation, whereas most of the environmental organisations are outreaches of wider movements, able to act quickly. There has been considerable recent change in the landscape of EU consumer organisations in recent years. Three organisations have disappeared entirely, while 
another two have lost funding from the Commission. The Consumer Policy Programme continues to seek to increase the participation of consumer organisations in EU policymaking, despite around 50 years of institutionalised dialogue.

Whilst BEUC is the sole European-level organisation dedicated to the representation of consumer affairs in public policy making, two further long established organisations include consumer issues within their domain. One is a producer association of the co-operative movement, (EUROCOOP), while another (COFACE) focuses more on family issues in its slimmed down format. A further organisation at the technical level is the European Association for the Coordination of Consumer Representation in Standardisation (ANEC), established in 1995. ANEC was originally established within the structures of BEUC, but is now an independent organisation in its own right, and which includes other EU consumer organisations within its governance structure. It is substantially funded by the Commission, enabling it to employ twelve staff, and involves experts in the technical work of 155 European and international standards committees, deployed in a quite deliberate way to act as a counterweight to industry in them. These are concentrated in some of the most sensitive areas such as child and vehicle safety, as well as household appliances, and general services such as post, tourism and road transport.

All of these organisations have supplemented their central resources by drawing upon those of its members, and BEUC has used this resource for particular needs. European Transparency Register data indicates that BEUC has an annual budget approaching $€ 5$ million, with 26 staff, as well as the ability to draw upon the substantial resources of its member organisations (the UK consumer organisations, for instance, employ around 400 staff). It has specialist organisational divisions responsible for legal affairs, food, health environment and safety, as well as departments for communications and training. These enable it to make a contribution to the detail of specific dossiers, enabling it to work across the range of issues in consumer affairs. Its relatively large legal department also equip it with the ability to handle conflictual relations where necessary (Wallace and Young, 1997). There have been highly conflictual relations, with DG Agriculture and Rural Affairs (DG AGRI) (Young, 1998), and with business interests, and in particular the pharmaceutical industry and automobile manufacturers. In the latter case, consumers have taken advantage of divisions among producer interests to form strategic alliances against the car companies with spare parts manufacturers and insurance companies (Young and Wallace, 2000). Other automobile campaign activities have included press and publicity drives to publicise price differentials and trade barriers, whistle blowing monitoring against individual manufacturers with DG Competition (Holmes and McGowan, cited in Young, 
1998), and in legal work, including supporting and working for referral of cases to the ECJ (Harlow and Rawlings, 1992). BEUC has been a contributory factor to similar work within the Commission which has clearly had an impact on the car market.

BEUC has long been able to make a contribution to the detail of debate on particular issues. In a generalised sense, the consistency of its market orientation with those of core single market objectives makes it easy to operate alongside its core partners in the Commission, although embracing members from high, and low, protection countries means that common platform building is not an easy task (Young, 1998). BEUC meets each incoming Presidency, and enjoys regular meetings at Director General level. BEUC went out of its way to welcome the Consumer policy strategy 2002-6, and has been involved in its delivery. A core of this strategy, and the Community action programme in consumer policy 2007-13, is capacity building for consumer organisations, and BEUC has delivered courses on Commission premises aimed at organisations from the new Member States on subjects such as lobbying the EU institutions, paid by the EU institutions. The history of institutionalised dialogue on consumer affairs with the European Commission has not been altogether happy, with decisions slow in forthcoming, highly prone to compromise, and members reluctant to defend them. In-fighting has characterised the history of institutionalised consumer consultative structures between the Commission and consumer organisations. The European Consumer Consultative Group (ECCG) comprises one member representing national consumer organisations from each Member State, and one member from each European consumer organisation (ANEC, BEUC). The Commission is free to ignore the decisions of, and rather little heed has been taken of them, or of those of its predecessors. Nonetheless, BEUC is represented in a range of advisory committees across the Commission.

Unsurprisingly given its quest to represent civil society, the European Parliament has been a kindred force for consumer interests throughout its existence. Its high-status Internal Market and Consumer Protection Committee (IMCO) has taken on the mantle of its predecessor as a forceful promoter of consumer interests and a consistent critic of the Commission for its failings in the consumer policy field. Consumer organisations have been able to use this route as a means of inserting amendments into Parliamentary business, and BEUC's resources are heavily drawn upon by individual MEPs.

To a certain extent, the impact of the European institutions and consumer organisations upon each other has been mutually reinforcing. Consumer organisations have played a 
part in producing a general climate whereby consumer interests are taken into account at the European level, and European manufacturers have embraced consumer needs and desires through higher product standards. For influences in the other direction, the European institutions have played a part in improving consumer representation, at both national and European levels. Industry in Europe has become more oriented towards quality in the manufacture of products. The EU has been a contributory climate to this, with a General Product Safety Directive (1992; revised 2001), placing on manufacturers a duty to monitor marketed products for safety. Under the provisions of this directive, firms now have a duty to assess and investigate consumer complaints, to identify product batches and to sample-test marketed products, while legislators can remove any product from the market for up to a year. These factors indicate how far consumer issues have come on the EU agenda since their 'symbolic' days. Where there is unavoidable conflict with business interests, so consumer organisations have been able to exploit the natural divisions between business. Whilst the EU agenda has been driven more by individual crises incidents than by consumer organisations, the wider discourse of a 'citizen's Europe' has made it an easier climate for consumer organisations to operate in. This discourse has enabled consumer organisations to increasingly work together on an issue basis with environmental, citizen, and social organisations.

\section{Social I nterests}

The development of organised social interests at the EU level hinged upon the European Commission until the arrival of the European Social Platform in 1995. Many Social NGOs originate from Commission initiatives aimed at creating a solid foundation for, and expansion of, European integration. The pattern of action in each case is very similar, with different outcomes. In the first instance, the Commission has taken the action of an initiative designed to create some momentum, such as a conference linked to a theme of the particular European Year of Action. Funds have been provided for a group by the Commission (sometimes historically on a doubtful legal basis), sometimes with little evaluation of the use to which funds have been put (Harvey, 1995) other than the knowledge that a support structure would be in place to carry demands for integration to member states. These have tended to be in safe fields where member states would find the agendas difficult to openly resist calls for action despite them inevitably commencing a road leading to further European integration, such as equality for women, for people with disabilities, and actions in the anti-racism field. The establishment of Community action programmes provide a firm foundation of resources to create, and support to 
nurture, NGOs in the field capable of taking the cause direct to the doors of member states. Once this process is in place, the Commission then proposes the strategy of mainstreaming. This is followed by an attempt to insert the issue in the Treaty, enabling further action programmes. While the first, 'best case' cause is being pursued, other, sometimes more difficult causes, are grouped together with the leading cause in a campaign for widely embracing action to be enabled under Treaty provisions. The 1997 Amsterdam Treaty provides a classic example of such a course of events. Following a sustained campaign by (then) DG V and social interest groups, told in further details below, Article 13 provided for 'appropriate action' to combat discrimination based on sex, racial or ethnic origin, religion or belief, disability, age or sexual orientation.

Two further, linked, cases enable further exploration of the Commission/public interest axis in developing European integration, and provide classic examples of the role of DG Employment and Social Affairs in preparing the groundwork for, and building on, the Article 13 agreement in the Treaty of Amsterdam. They also demonstrate the limits to, and constraints of, Commission action in working with groups to develop European integration. To support the campaign for Article 13 in the Amsterdam Treaty, DG EMPL (then DG V) proposed that 1997 be designated the European Year Against Racism. It added a €7m funding package for projects in that year including support for NGOs, the establishment a European Monitoring Centre against Racism and Xenophobia, and a major network event in Brussels bringing together 130 anti-racism organisation to form the European Network Against Racism. The following year, 1998, with Article 13 safely in the Treaty, saw the Commission Action Plan against Racism, with 176 projects funded, and an attempt by DG $\checkmark$ to introduce new legislation on mainstreaming (Guiraudon, 2001).

The Commission's work on anti-racism dates from 1986. In support of this work, the Commission acted on an initiative of the Parliament to establish the (now defunct) European Union Migrants' Forum (EUMF) in 1991, actively intervening to shape the group's parameters and operations during its turbulent history (Geddes, 2000; Guiraudon, 2001). A later group was the Starting Line Group (SLG), a group of activist lawyers. SLG helped in the first instance by preparing a draft directive outlawing racial discrimination, modelled on the 1976 Equal Treatment Directive (Geddes, 2000; Case and Givens, 2010). Whilst this was never implemented, post Amsterdam SLG brought forward another proposal for a Directive putting into effect the principle of equal treatment (Geddes, 2000). Geddes comments 
It is possible to detect the influence of the SLG's proposals on policy development within the Commission, (p.644)...pro migrant lobbying at EU level has centred on the building of alliances between lobby groups and sympathetic EU institutions, particularly the Commission and the EP (Geddes, 2000, p.645.)

Similarly, Case and Givens stress the impact of the SLG, but in particularly, the support of the Parliament to do so, where there is a significant Intergroup on Anti-Racism and Diversity. The European Network Against Racism (ENAR), established in 1998 as an outcome from the 1997 European Year Against Racism, also claims some responsibility for the Commission launch of a new non-discrimination Directive in 2008, covering aspects of discrimination beyond the workplace. ENAR is a core partner of a DG EMPL funded programme on 'promoting strategic litigation' that trains NGOs to identify test cases to bring forward which seem likely to push forward the frontiers of EU policy competencies in the field (Case and Givens, 2010).

A similar pattern of Commission activism is evident from the case of homelessness, although the outcome has not resulted in an extension of EU competencies. In 1989 the Commission used a generous interpretation of a general clause in the Treaty of Rome (improving quality of life) to fund a conference on homelessness and housing provision. This was a subject in which there are very few EU competencies, and the conference was funded in the hope of kick-starting initiatives and finding a more permanent demand constituency that would be a supporting measure for European integration. It invested some effort into the creation of a group that emerged from the conference, the European Federation of National Organisations Working with the Homeless (FEANTSA). The Commission found useful things for FEANTSA to do, such as designating it with official 'observatory' status to supply it with information on the state of homelessness in Europe. The example is a highly typical one of each of the stages and the specific measures taken by the Commission to work with NGOs as agents of integration. Yet more than two decades later, beyond the generation of reams of information, neither the Commission nor FEANTSA have much to show by way of changes to EU competencies in the housing field, other than generalised credit among a specialised community for taking forward a social measure.

The FEANTSA case lends support to an alternative interpretation, of the Commissionsocial NGO relationship as a 'frothy' one, generating much noise but little by way of hard achievement. Whilst DG Employment and Social Affairs has rolled out programme after programme in social fields, with measures such as anti-racism and anti-poverty, the 
impact is little more than symbolic. The anti-poverty programmes, for instance, had a budget of €55 million over a five-year period, supporting small-scale 'pilot projects', research, and networking needs of interests groups, in the context of an estimated 50 million plus EU citizens being trapped in poverty. In this view, actions such as theme years' of 'Solidarity Between Generations,' 'Anti-Racism' 'Languages' and 'Sport' have been empty shells.

'Social Europe' has its origins as a series of measures adjunct to the single market. Until the Commission Green Paper on Social Policy in 1993, 'social Europe' in 'Euro-speak' meant workers' rights. The soundest legal basis in the Treaties for 'social policy,' until Article 13 of the 1997 Amsterdam Treaty became the gatekeeper for more traditional social policy, arose from measures to ensure a level playing field in production between the member states in the single market. Thus, the Treaty of Rome contained provisions for equal treatment of men and women, social security for migrant workers, and health and safety of workers, which came to be governed by QMV by later Treaty changes (Wendon, 1997). In fields that could easily be related to employment, such as equal opportunities, training, exclusion from the labour market, disability, and protection and movement of workers, the Commission has had little trouble in developing and funding programmes and initiatives. Interest groups in the fields of women's rights, young people, disabilities and refugees became well established and resourced, and well embedded into their patron's corners of the Commission. A caveat is that each of fields spawned multiple organisations working within them, despite the presence of leader organisations. One of these examples concerns the representation of women, where a combination of circumstances makes it another 'most likely scenario' case to consider the impact of public interest groups on European integration.

The mixture of the EU labour market focus, an irresistible policy frame of equality, a committed patron, a strong network of grassroots organisations, and the ability to work in institutionalised politics, combines to create a favourable set of circumstances for EU women's organisations. The Commission and the ECJ have become powerful institutional advocates of EU equal opportunities policies (Mazey, 2000), and the women's movement has long been embedded within DG Employment and Social Affairs (Mazey and Richardson, 1999). The European Women's Committee was among the first advocacy organisations to emerge, in 1984, created by a group of women working in the European Commission, seeking to build upon dramatic successes achieved in the European Court of J ustice arising from the 1976 Defrenne case. Once again, the Commission was the first and main activist 
on the EU scene, and funded conferences the first vehicle for action. These factors gave rise to a series of densely organised European women's advocacy and network organisations covering a variety of niches, with, by 2010, around 55 women's organisations active at EU level. The lead organisation, EWL, was itself formed in 1990 from a coalition of traditional and radical feminist women's groups. Its member organisations, comprising organisations in 31 countries and 19 European wide networks, themselves embrace over 2000 member organisations. It uses this network to undertake EU public education campaigns in the member states, undertaking 'roadshows' to explain the potential impact of new Treaties, and satellites its board meetings around different national venues. These efforts make it notable among the wider constituencies of EU interest groups by seeking to engage with citizenry direct, and popular within the EU institutions, particularly within DG Employment where it is heavily institutionalised (Mazey, 2000). A past secretary general of the EWL who went on to work in the Commission has reflected that its 'survival and effectiveness depend on friendly individuals inside the European Parliament and Commission' (Helfferich and Kolb, 2001, p. 148). The expected close relationship between the EWL and the Women's Committee of the European Parliament has been confirmed by Cullen (Cullen, 1999).

At a very early stage, the Commission established a Women's Employment and Equality Office inside the Employment and Social Affairs Directorate responsible for policy promotion and co-ordination (Harlow and Rawlings, 1992), and which later became the Equal Opportunities unit (Pollack, 1997). Gender equality at work came under QMV rules at the TEU, while the Treaty of Amsterdam introduced a number of significant new gender equality initiatives, including provisions applying beyond the labour market, gender mainstreaming, and a new provision for equal pay for work of equal value (Helfferich and Kolb, 2000). A number of other gender equality provisions were also reinforced, such as those enabling member states to take 'positive actions' in the labour market, and antidiscrimination provisions. Helfferich and Kolb remark that Treaty amendments passed to extend gender equality at the Amsterdam Treaty were

at least partly the result of a co-ordinated lobbying campaign of the European women's movement spearheaded by the EWL (Helfferich and Kolb, 2000, p.143),

and that the EWL was

one of the few European public interest groups in the social policy field that was 
successful in having its demands taken by the governmental representatives negotiating the new Treaty (ibid., p.144)... the active campaigning of the EWL was crucial for the extent of the changes (ibid., p.147.).

According to these authors, EWL's Spanish member convinced the Spanish government to adopt EWL positions as their own, and from there got the position into Treaty negotiations. The authors do specify that the final outcome would fall well short of the Lobby's expectation, but it was nevertheless greeted as a success by the organisation' (ibid.). A further, stronger dose of caution should be added to the interpretation reached by the authors, in that the story is told by a former secretary general of the EWL at the time of the 'campaign', who claims that the EWL went 'one step further than the other groups working on the treaty revisions' (p.156). Just as the ERT was not the prime agent responsible for the single market, so neither was EWL single-handedly responsible for the measure in the Treaty. The authors do acknowledge that the 'campaign' came at the right time, when there was considerable concern within elite circles that there might be a repeat of the TEU scenario and a rejection of the Amsterdam Treaty. Other authors, too, have lent a similar interpretation. Mazey has argued that women's organisations have been important agents in the adoption of mainstreaming strategies in EU and member states. Using similar arguments to those presented by Helfferich and Kolb, Mazey has highlighted the importance of mobilising networks and 'political opportunity structures,' and draws upon her earlier work to outline the importance of a sympathetic 'policy frame' in the relevant DG in determining the degree to which mainstreaming has had an impact (Mazey, 2000).

The European Commission has successively launched five year strategy programmes for equality between men and women. The Civil Society Contact Group (CSCG) claims that the adoption of the 2006-10 programme arose from lobbying by the European Women's Lobby, noting that

it covers approximately the same areas as the EWL Roadmap and contains some of the same vision and strategies for gender equality, although the official measures foreseen are not as strong, far reaching, and precise as the ones suggested by the EWL text (CSCG, 2006, p.17).

Similarly, in 2010 the EWL issued a press release in which it 'welcomed the launch of the EU's much anticipated new five year strategy for equality between men and women', 
noting in particular how 'women's rights groups are positive towards the envisaged annual top-level Gender Equality Dialogue amongst key stakeholders and stress the importance of the presence of key women's organisations at such fora' (EWL, 2010). The latter is a further reference to the continued institutionalisation of EWL, with the dialogue involving, inter alia, the Parliament, Commission, Member States, Council Presidencies, and the EWL. This picture of an organisation granted a quasi-monopoly in representation in return for pursuing an insider strategy is confirmed in a recent analysis by J acquot and Vitale (2014). Johansson and Lee show how this position is enforced by EWL screening member applications for conformity of viewpoint (J ohansson and Lee, 2014). As a systemic insider, the EWL works differently from organisations based on popular mobilisation, the characteristic of social movement organisations.

\section{Social Movements}

The increasing engagement of the European Union by 'social movements' has been viewed in a more or less hopeful way by a number of commentators (Tarrow, 2006; della Porta, 2007; Erne, 2009; Crespy, 2014; Parks, 2015). Della Porta claims that

it is possible to already delineate some elements of an emerging European movement, in which a set of organizations and discourses are interwoven in extremely flexible organizational structures, with identities that are tolerant of difference. Common denominators of such mobilizations that seem anything but a passing fad include demands for social rights and a democratization of European institutions, not least through the creation of a supranational, critical public sphere (della Porta, 2007, p.205).

Such movements appear to be drawn more from globally orientated activism rather than national origins (Tarrow, 2006), ironically mainly to the theme of 'anti-globalisation'. A common feature of 'new social movements' are their 'alternative' perspectives'. Leigh cites the way in which Anheir, Kaldor and Glasis characterise this as

an experiment in and demonstration of new ways of living and new types of social relations - non-hierarchical and consensus-based (Leigh, 2009, p.5).

A key issue concerns the point at which - and whether - a distinction can be drawn between organisations which are 'social movements' and those which are part of the 'usual 
circuit' of Brussels based institutionalised NGOs. A usual caricature is that between advocacy 'insiders' to activist 'outsiders' (Tarrow, 2006), ranging from institutionalised charities headed by royal patrons through to the ATTAC (Association for the Taxation of Transactions for the aid of the citizen) network and beyond to 'loosely affiliated anarchists' at the other extreme (Hadden, 2009, p.13). There are normative overtones conveyed by labels such as 'new' social movements, or idealised juxtapositions between 'professionalised and bureaucratised associational civil servants' on the one hand, and 'radical' organisations populated by 'grass-roots activists' (Saurugger, 2009) pursuing 'the politics of the street' (ref.). This is to some extent also evident in Saurugger's definition of a social movement as

collective challenges to existing arrangements of power and distribution by people with common purposes and solidarity in sustained interaction with elites, opponents and authorities (ibid., p.8).

A key point is the extent to which the activities of such actors contribute to, or detract from, EU legitimacy. Is, for instance, the occupation of business association offices (there were such incidents at CEFIC, and ERT) by activists to be interpreted as a positive sign of engagement and populating the public space with debate? Erne claims that 'most political scientists concur that social actors contribute to Euro-democratization if they contribute to the rise of a European public sphere' (Erne, 2009, p.2). He argues that

social actors contribute to Euro-democratization if they contribute to the making of a European public sphere, act collectively on a European level, and politicize the EU integration process in the transnational European public sphere (Erne, 2009, p. 4).

Hadden takes a critical view of the message that 'any engagement is a positive contribution to legitimacy by creating a public space' on the basis of an assessment of the activities and perspectives of 37 organisations and a variety of activists. She casts the perspectives of 'radical' organisations based around anti-globalisation lenses as potentially de-legitimising for an EU seen by such activists as broadly pro-liberal. Her analysis confirmed the presence of two distinctive segments of actors at EU level, split between 'conventional' actors and those that use 'contentious actions', with organisations such as Greenpeace acting in a brokering role as a bridge between these two worlds (Hadden, 2015). Nonetheless, some organisations are forced to play the institutionalised game by the need for policy advocacy and funding (Leigh, 2009; see also Sikkink, 2002). There 
are also 'hybrid' cases where 'protest and institutionalised contention go hand in hand, with some actors among civil society pursuing dual strategies' (Crespy, 2009, p.16). The European Social Forum has been a venue for these various types of players to meet, with participants balanced more towards 'outsider' than 'insider' organisations (della Porta, 2007). The Forum has met on a more or less bi-annual basis since shortly after the 'battle of Seattle', but there are preparatory meetings four times yearly with up to 400 activists present at events (Doerr, 2009).

Ruzza shows how social movements have found a niche which fulfils a variety of functions they need to meet (Ruzza, 2011). They become 'norm entrepreneurs' at EU level, bringing ideas into the EU environment and contributing to otherwise limited understanding of issues, as well as providing a voice for otherwise marginalised parts of civil society, and a check and balance upon producer orientated lobbies. Sometimes they put forward an often utopian vision of desirable policy change that other more moderate organizations can utilise as a negotiating standard. Characterising a type of organisation which lie somewhere between traditional social movements, and institutionalised actors in the political system, he moves beyond traditional caricatures of once independently minded organisations whose destiny is to become progressively institutionalised and removed from their grass roots origins. He identifies a set of intermediate organizational forms that retain some of the features of social movements but have also acquired some of those distinctive of NGOs, including a degree of professionalization, service delivery roles, and better legal skills. Direct representation arises through organisations which are part of the social movement 'family', such as Greenpeace and Friends of the Earth, but who can also play the 'institutional politics' game, apparently without too much compromise or tension (Ruzza, 2011). These 'broker' organisations are highly skilled in alliance-building; they were key agents in the formation of the ALTER-EU alliance in the creation of the European Transparency Register (Chapter 3), and where required they build alliances with producer organisations for common cause campaigns, such as genetically modified organisms (GMOs) (Parks, 2009a). The ability to create alliances with producer constituencies is also a noted skill of WWF, considered earlier in this chapter.

Protest and direct action have always been the traditional tools of 'outsider' movements, now facilitated, empowered and extended by the use of 'cyberactivism' (Thomas, 2004). The key point is that the internet allows activists to find and communicate with each other, to engage in attacks on the IT domains of opponents ('hacktivism') and provides an unprecedented platform for mobilisation and broader public communication. The latter 
has been used in a way which is orientated towards public accountability of either political institutions or opponents, influencing public policy through public message, and by confronting opposing interests. Web sites are carefully constructed in a way to attract the casual browser, using satire as a weapon (Balme and Chabanet, 2008), aimed at striking chords with populist outlooks about the influence of finance in politics.

At EU level, these activities have been used in a way to de-legitimise the EU polity (Balme and Chabanet, 2008), with opposition to the European services directive proposed by Commissioner Bolkestein a particular rallying point, and a means of connecting with institutionalised NGO actors in the EU system. Crespy notes how

The Bolkestein Directive therefore constitutes a hybrid case where protest and institutionalised contention go hand in hand, with some actors among civil society pursuing dual strategies (Crespy, 2009, p.16).

Of significance is that mobilisation on the Services Directive was particularly aimed at the European Parliament (Fazi and Smith, 2006), making the direct connection between citizens and their representative organisation. This aspect also drew in traditionally 'outsider' organisations to institutionalised EU public policy making (Crespy, 2009; Parks, 2009a). This included groups such as ATTAC, who also become draw in during the early days of dialogue with DG Trade and during the Convention period drafting the constitutional treaty, and through the ALTER-EU alliance (Chabanet, 2006) (Chapter 3). Crespy, and Parks, take a more benign view of the role of contention, seeing it as a prerequisite for democratisation through popular mobilisation, and the presentation of alternative choices in the public sphere (Crespy, 2014; Parks, 2015). In this account, trade union organisations, notably, link with social movements to convey contention to and from civil society and EU institutions, in a political system otherwise noted for producing 'policies without politics' (Schmidt n.d., in Crespy, 2014, p.85). The orientation of the EU system to consensus may, paradoxically, make it more receptive to shock tactics' of popular mobilisation (Leiren and Parks, 2014; Parks, 2015). The Trade Union movement has proved adept at popular mobilisation, including confrontational demonstrations in front of the European Parliament, apparently to decisive effect (Leiren and Parks, 2014).

Mobilisation by internet activists have also featured among 'repertoires of action' (Parks, 2015), with a notable example provided by the rejection by the European Parliament of 
the European Commission's proposal that Europe sign the global anti-counterfeiting treaty (ACTA). The EP was initially favourably disposed towards the Treaty, but a decisive moment came when Wikileaks revealed drafts which framed the issues as going well beyond counterfeiting, to include trade in generic medicines, and controversial rights for Internet Service Providers (ISPs) to deny service to miscreants in a '3 strikes and you're out' measure, framed as including friends sharing music files (Parks, 2015). The campaign against the measure, conducted by a mixture of internet activists and NGOs, was decisive, resulting in an overwhelming rejection by the EP. Internet activists have also been in the forefront of campaigns for internet neutrality, which the European regulator recently upheld through placing strict conditions on the conditions under which internet service providers can 'throttle' or accelerate services. The strict General Data Protection Regulation of 2016 , where offending companies can be fined $4 \%$ of global turnover, is also a reflection of the strong politicisation of internet related politics. The rejection by the European Parliament of the proposed software patent directive in 2005 provided a landmark point for popular politicisation of EU IT related politics (Gehlen, 2006). The EP has proved to be particularly attuned to public sentiment, keen to parade its credentials as a popular tribune whenever issues reach high public saliency (chapter 2 ).

\section{Conclusion}

The breadth and depth of citizen interest mobilisation at EU level is substantial. New organisations are constantly emerging to fill advocacy causes and niches, now extending to embrace social movements. 'Family' organisations and networks of cognate NGOs have emerged with purposeful co-ordination and a division of labour between them. A range of issue alliances across segments demonstrate the presence of a 'citizen interest community'.

Of the three segments of citizen interests reviewed in this chapter, environmental interests appear to be the most organised, related not only to the resources upon which they can draw, but also to the breadth and range of advocacy organisations and the niches they fill, the structures which link them together, and the power of the environmental discourse in Europe. Their impact can be demonstrated not only in fields of agendasetting, but some way beyond. Niche organisations in the social/citizen field are by now also highly established, as well as institutionalised. Whether organisations which receive more than three-quarters of their funding from the EU political institutions are well placed to help political systems develop input legitimacy will always remain an open question. 
However, a new development since the last edition of this book has been the diversification of funding sources for NGOs. Consumer affairs present a slightly different story, although the main NGO in the field is very well resourced. Here, significant policy landmarks have arisen not from agenda setting by consumer groups, but from crisis events involving food or consumer product safety, and from the quest by EU institutions for output legitimacy through the pursuit of populist measures, such as regulating cross border mobile phone roaming charges.

Together, a whole range of issues arise from this chapter for the democratic legitimacy of the EU, and particularly the extent to which the activities of interest organisations as well as engagement of the EU by social movements can be a route to the democratic legitimacy of the EU. These are considered in chapter 8. 